\title{
Iranian EFL Learners' Perceptions with Respect to Speech Acts in Comparison with the Actual Content of the Textbooks*
}

\author{
Mohsen Sa'di Khosroshahi \\ University of Tabriz, Tabriz, Iran \\ Farahman Farrokhi \\ English Department, University of Tabriz, Tabriz, Iran
}

\begin{abstract}
The perceptions of the EFL learners have been ignored in most of the textbook evaluation studies in Iran. This study aimed to make a comparison between the attitudes of Iranian EFL learners towards speech acts and the actual content of their textbooks. To this end, a descriptive and survey-based design was employed. A questionnaire was distributed among 100 first-year high school students in four schools. The first-year high school English textbook was also carefully analyzed with respect to the different types of speech acts. A comparison was made between the results obtained from the questionnaire analysis and the results of the content analysis of the textbook, which revealed the fact that the students generally had a positive attitude towards the teaching of speech acts. On the contrary, they rated the Language Functions Section in their textbook to be ineffective in terms of the teaching of speech acts. A closer examination of the dialogues in the Language Functions Section revealed that the range of speech acts covered in the textbook is extremely limited. These findings show that there are gaps between the Iranian learners' perceptions and the actual content of their textbooks. The findings can be useful to the textbook designers as well as language teachers.
\end{abstract}

Index Terms - textbook, textbook evaluation, needs analysis, speech act

\section{INTRODUCTION}

Course books and the teacher are considered to be the main sources of input in EFL contexts. Nevertheless, studies have demonstrated that course books fall short of including the necessary input. This is especially true in the case of authenticity and coverage of important aspects of speech acts (Vellenga, 2004). Speech acts is not a new topic. In fact, they have been popular since they emerged in the late 1960s. The framework offered by Canal and Swain, which is a framework of communicative competence, caused a revolution in the field of language teaching by helping communication to be regarded as the ultimate goal of language learning. This led to speech acts coming into focus again because speech acts are the functions of language. Being a popular topic in the field of language teaching, speech acts has been offering research opportunities since the number of problematic areas in the process of teaching speech acts is on the rise, which necessitates clarification by further research (Baleghizadeh, 2007).

\section{REVIEW OF THE RELATED LITERATURE}

\section{A. Arguments for Using Textbooks}

The researchers who emphasize on the necessity and usefulness of textbooks can be said to fall into two groups. The first group of researchers argues that textbooks are a psychological need for teachers and learners alike. For example, Hutchinson and Torres (1994) suggest that the textbook is an almost universal element of English language teaching without which any teaching-learning situation is practically incomplete. Haycroft (1988, as cited in Amiryousefi \& Ketabi, 2011) believes that students see textbooks as being useful to the measurement of their achievement and progress. Similarly, Sheldon (1988, as cited in Amiryousefi \& Ketabi, 2011) believes that from the learners' perspective, textbooks have more validity and credibility compared to in-house materials. Also, textbooks are cheaper and more accessible than such materials and require less preparation time. Therefore, textbooks can reduce cognitive and occupational loads on both teachers and learners. Textbooks also can be useful in providing novice teachers with a sense of security, guidance and support (O’Neill, 1982).

The second group of researchers argues for the necessity of textbooks because they see the textbook as a repertoire of materials, exercises and activities, a reference source, a pre-determined syllabus, and a source of creativity which reflects research findings and learners' needs. This group believes that textbooks are systematic and thus give teachers and students an overall view of the course and syllabus, and also can inform them of where they are in the course at

\footnotetext{
* It is to be noted that this study is based upon the M.A. thesis of the first author to be presented at the University of Tabriz.
} 
present and where the course is going, while teacher-made materials are normally prepared weekly and are more likely to lead to a gap and lack of systematicity in both teaching and learning (Harmer, 2001). Textbooks also offer new activities and methodologies to which teachers can add local data should they find it necessary. In this way, textbooks can stimulate, change and expand teachers' repertoire (Harmer, 2001).

\section{B. Textbook Evaluation}

According to Tomlinson et al (2001), as an activity in the field of applied linguistics, textbook evaluation enables teachers, supervisors, administrators and materials developers to make judgments about the effects of materials on the end-users; i.e. learners. McGrath (2002) believes that textbook evaluation is important for the development and administration of language learning programs.

The primary goal of learning English in Iran is to help promote a universal understanding by familiarizing students with science, literature, and art of English speaking countries and providing them with a mean of finding and accessing sources of information in English (Birjandi \& Soheili, 1982, as cited in Rahimi \& Hassani, 2012). Failing to achieve these goals in Iranian language classes has caused the national EFL curriculum to be carefully scrutinized in order to find the sources of the demotivation of students and the reasons behind the failure of language programs in Iran. Research findings suggest that one of the sources of the inefficiency of the EFL curriculum in Iran is the English textbooks (Rahimi, \& Nabilou, 2009), which serve as both the syllabus and main guideline for English teachers.

Textbook evaluation studies in Iran have focused on investigating the inefficiency of language teaching materials from teachers' perspective (Moradi, 2008, as cited in Rahimi \& Hassani, 2012). However, the attitudes of students towards their EFL textbooks have been ignored in the evaluation of materials in Iran. Any language policy and planning needs to take into account the attitudes, needs, and interests of the target group for whom a textbook is designed (Lewis, 1981 cited in Baker, 1992, as cited in Rahimi \& Hassani, 2012).

A few studies have been carried out in Iran in order to evaluate textbooks. For example, Yarmohammadi (2002) found that high school textbooks suffer from a number of shortcomings, such as ignoring oral skills and the interchangeable use of English and Persian names. Ansary and Babaii (2002) provided an outline of the common core features of standard EFL/ESL textbooks, and reached the conclusion that not every textbook would have these features. Amalsaleh (2004, as cited in Azizifar, 2010) investigated the representation of social factors in both junior and senior high school textbooks and showed that textbooks present stereotypical views of females and males in society. Rahimi and Hassani (2012) investigated Iranian high-school students' attitude towards their EFL textbooks and its role in their attitude towards learning English as a foreign language and found that in general students do not have a positive attitude towards their English textbooks.

\section{Needs Analysis in EGP (English for General Purposes) Courses}

Compared to ESP (English for Specific Purposes) courses, general English courses do not show much concern for learner needs because it is wrongly assumed that specifying the needs of general English learners is not possible, and partly because there is a dearth of literature on the practicalities of analyzing the data obtained from Needs Analysis in the context of general English (Seedhouse, 1995). The results of a study by Seedhouse (1995) revealed that the primary reasons for the learning motivation of the Spanish students in EGP courses were psychological and social. His study shows that students in EGP courses have a clear understanding of what they need, and that findings from Needs Analysis could be useful for EGP course design, classroom implementation, and evaluation. Seedhouse's study helps validate Nunan's (1988, as cited in Liu et al, 2011) and Richards' (1990, as cited in Liu et al, 2011) stance on the issue. They both believed that it was possible to discern the needs of students in EGP courses through the application of Needs Analysis in EGP courses.

\section{The Importance of Learner Preferences in Textbook Designing}

Bell (1983, as cited in Nunan, 1988) claims that while some teachers freely design the syllabuses they use in their teaching programs, most teachers are mainly consumers of other people's syllabuses. Their role is mainly to implement the plans offered by applied linguists, government agencies, and so on. Considering the fact that the syllabus imposed by the textbook has a close relationship with what the teacher does in the class and how she does it, it is important to design the textbook in a way that will encourage the teaching of the material in such a way that will ensure maximum language acquisition. In so doing, it is important to take into consideration the preferences of learners in the designing of the textbook and classroom activities so as to increase the learners' intrinsic motivation.

\section{E. Speech Acts}

The British philosopher J.L. Austin proposed the speech act theory, which was later developed by another philosopher John Searle. Austin's initial insight was that people do not simply make statements that can be judged as "true" or "false", rather, they use language to perform actions that have an impact in some way on the world. The concept of performative utterance was developed in the 1950s by Austin. He distinguished between two kinds of utterances: constative utterances and performative utterances.

Constative utterances make a statement, describe a state of affairs, and are either true or false. An example of a constative utterance is: "John promised to pay me." Performative utterances are not true or false and actually perform 
the action to which they refer. For example, the utterance "I promise you to be there." performs some action, namely the act of promising (Culler, 2000).

Both Austin and Searle (1969, as cited in Culler, 2000) tried to classify speech acts into different categories, and to identify the 'felicity conditions' for the successful performance of a speech act (Schmitt, 2002). Based on Austin's (1962), and Searle's (1969) theory, Cohen (1996) identifies five categories of speech acts based on the functions assigned to them:

- Assertives / Representatives commit the speaker to something being the case.

- Directives try to get the addressee to perform an action.

- Commisives commit the speaker to doing something in the future.

- Expressives express how the speaker feels about the situation.

- Declarations change the state of the world in an immediate way. (Jaworowska, 2012).

John Searle helped improve the classification of speech acts based on a distinction between two "directions of fit" between language and reality - from word to world, and from world to word. Assertives have a word-to-world direction of fit; directives and commisisives have a world-to-word direction of fit; Expressives have no direction of fit; and Declaratives bring about the fit between word and world as long as they are performed successfully (Smith, 2003).

\section{F. The Importance of Speech Acts in Language Learning}

Some students are able to produce sentences that are grammatically well-formed; however, being grammatically correct does not necessarily mean that their well-formed sentences are appropriate for the context within which they are employed. An example of a learner, who has an acceptable level of grammatical competence but lacks the skill to communicate appropriately, is one that in response to "Could you open the window?" says "Yes, I could." (Baleghizadeh, 2007). The present study seeks to answer the following questions:

Research Question 1: How effective are speech acts in the learning of English from the perspective of Iranian high school students?

Research Question 2: How effective is the Language Functions section of the textbook in the learning of English from the perspective of Iranian high school students?

Research Question 3: What is the range of speech acts taught in Iranian high school textbooks?

\section{METHODOLOGY}

\section{A. Participants}

A total of 100 first-year high school students whose ages ranged from 15-16 participated in this study. The participants were all bilingual speakers of Turkish and Persian. All participants were male and were randomly chosen from four high schools.

\section{B. Design of the Study}

A descriptive, survey-based design was employed in this study. A translated version of the questionnaire in Persian was distributed among the participants, which included Likert-type items. Afterwards, the Language Functions Section of the first-year high school English textbook was analyzed. Finally, a comparison was made between the results of the textbook analysis and the perceptions of the first-year high school students.

\section{Materials}

The questionnaire used in this study was divided into two parts. The first part presented the students with different samples of speech acts along with example dialogues. 10 questions followed the sample speech acts to provide the students with the opportunity to express their attitudes towards speech acts by answering Likert-type questions.

10 Likert-type questions were included in the second part of the questionnaire, which were intended to elicit their attitudes toward the actual content of their textbook; i.e. the Language Functions Section in their textbook.

\section{Procedures}

After obtaining the permissions from the Ministry of Education, the questionnaire was distributed in four high schools. The first version was pilot-tested with 15 participants. The second version was pilot-tested with 25 students and distributed among other high schools. The first-year high school textbook was analyzed in terms of the range of speech acts. Finally, the results of the questionnaire analysis were compared to the results of the textbook analysis. The data analysis results were also double-checked by another coder, which showed that the inter-rater reliability was $95 \%$.

\section{Data Analysis \& Results}

\section{A. Descriptive Statistics for Research Question 1}

The results of questions 1-10 in the questionnaire, which represent the first macro-category; i.e. "the effectiveness of speech acts in language learning from learners' perspective" are demonstrated in Table 1. 
TABLE 1:

THE RESULTS OF THE ANALYSIS OF QUESTIONS 1-10 IN THE QUESTIONNAIRE

\begin{tabular}{|c|c|c|c|c|c|}
\hline & Highly effective & Somewhat effective & I do not know & Somewhat ineffective & Highly ineffective \\
\hline 1 & \multicolumn{5}{|c|}{ How effective can practicing such speech acts be in making language learning enjoyable? } \\
\hline & 52 & 27 & 7 & 7 & 7 \\
\hline 2 & \multicolumn{5}{|c|}{ How effective can learning such speech acts be in increasing your motivation to speak in English? } \\
\hline & 51 & 28 & 10 & 5 & 6 \\
\hline 3 & \multicolumn{5}{|c|}{ How effective can learning such speech acts be in causing you to see a reason for learning English? } \\
\hline & 29 & 43 & 11 & 12 & 5 \\
\hline 4 & \multicolumn{5}{|c|}{ How effective can learning such speech acts be in providing you with the opportunity to practice what you have learned thus far? } \\
\hline & 31 & 37 & 13 & 9 & 10 \\
\hline 5 & \multicolumn{5}{|c|}{ How effective can practicing such speech acts be in improving your vocabulary knowledge? } \\
\hline & 42 & 37 & 7 & 6 & 8 \\
\hline 6 & \multicolumn{5}{|c|}{ How effective can practicing such speech acts be in increasing your mastery over grammatical structures? } \\
\hline & 42 & 38 & 12 & 4 & 4 \\
\hline 7 & \multicolumn{5}{|c|}{ How effective can practicing such speech acts be in improving your pronunciation? } \\
\hline & 38 & 40 & 11 & 6 & 5 \\
\hline 8 & \multicolumn{5}{|c|}{ How effective can learning such speech acts be in carrying out in-group interactions while performing role-playing tasks? } \\
\hline & 48 & 29 & 7 & 9 & 7 \\
\hline 9 & \multicolumn{5}{|c|}{ How effective can learning such speech acts be in helping you to speak appropriately (the same way native English speakers do)? } \\
\hline & 48 & 31 & 8 & 4 & 9 \\
\hline 10 & \multicolumn{5}{|c|}{ How effective can learning such speech acts be in fulfilling your daily needs (for reading stories, watching movies, etc.)? } \\
\hline & 50 & 26 & 5 & 7 & 12 \\
\hline
\end{tabular}

As Table 1 shows, most of the students' responses are distributed in the effective end of the continuum. The difference between the number of the responses rating the teaching of speech acts as effective and the number of those rating them as ineffective is significant. Table 2 presents the percentages for questions 1-10 in the questionnaire.

TABLE 2:

THE PERCENT AGES FOR QUESTIONS 1-10 IN THE QUESTIONNAIRE

\begin{tabular}{|l|l|l|l|l|}
\hline Highly effective & Somewhat effective & I do not know & Somewhat ineffective & Highly ineffective \\
\hline The Total Number of the Selected Options & 91 & 69 & \\
\hline 431 & 336 & 73 & \\
\hline The Percentage of the Selected Options & $9.1 \%$ & $6.9 \%$ & $7.3 \%$ \\
\hline $43.1 \%$ & $33.6 \%$ & $14.2 \%$ \\
\hline The Merging of the Percentages of the Selected Options & $9.1 \%$ & \\
\hline $76.7 \%$
\end{tabular}

As Table 2 shows, the percentages of the responses rating the teaching of speech acts to be effective $(76.7 \%)$ are significantly higher than the percentages of those that rated them to be ineffective $(14.2 \%)$. The results of the analysis of questions 1-10 in the questionnaire are demonstrated in Fig. 1. Fig. 1 illustrates the results presented in the third row of Table 1 which merges the percentages in the second row of Table 1.

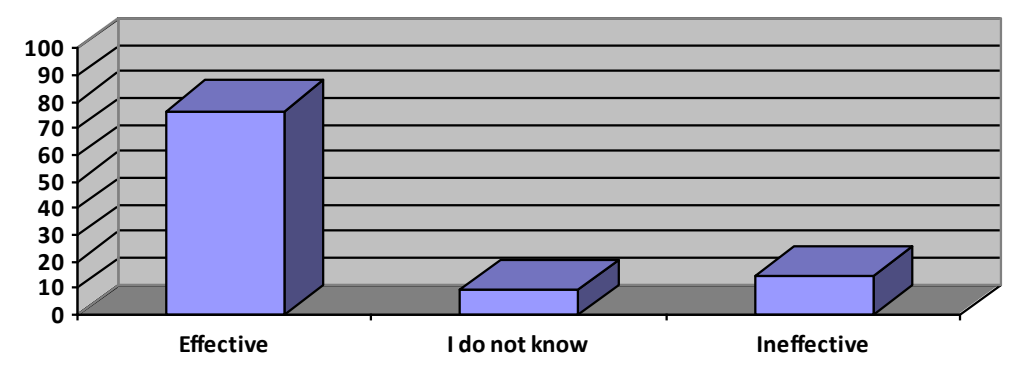

Figure 1.The merging of the results of the analysis of questions 1-10 in the questionnaire

As both Table 1 and Fig. 1 demonstrate, $76.7 \%$ of the responses rated the learning of speech acts as being effective in the overall learning of English and $14.2 \%$ considered them as being ineffective. $9.1 \%$ of the responses were indeterminate.

\section{B. Descriptive Statistics for Research Question 2}

The results of questions 11-20 in the questionnaire, which represent the second macro-category; i.e. "the effectiveness of the Language Functions Section of the textbook in language learning from learners' perspective" are demonstrated in Table 3. 
TABLE 3:

THE RESULTS OF THE ANALYSIS OF QUESTIONS 11-20 IN THE QUESTIONNAIRE

\begin{tabular}{|c|c|c|c|c|c|}
\hline & Highly effective & Somewhat effective & I do not know & Somewhat ineffective & Highly ineffective \\
\hline 11 & \multicolumn{5}{|c|}{ How effective is the "Language Functions" section of your textbook in increasing your motivation to speak English? } \\
\hline & 11 & 19 & 11 & 31 & 28 \\
\hline 12 & \multicolumn{5}{|c|}{ How effective are the dialogues in the "Language Functions" section of your textbook in enabling you to speak in English? } \\
\hline & 3 & 22 & 10 & 43 & 22 \\
\hline 13 & \multicolumn{5}{|c|}{ How effective are these dialogues in familiarizing you with various speech acts? } \\
\hline & 3 & 12 & 23 & 35 & 27 \\
\hline 14 & \multicolumn{5}{|c|}{$\begin{array}{l}\text { How effective are the dialogues in the "Language Functions" section of your textbook in making these dialogues meaningful to you? (for } \\
\text { example, by giving information on the speakers involved or presenting you with pictures) }\end{array}$} \\
\hline & 6 & 14 & 18 & 34 & 28 \\
\hline 15 & \multicolumn{5}{|c|}{$\begin{array}{l}\text { How effective are the dialogues in the "Language Functions" section of your textbook with respect to presenting you with information on } \\
\text { the situation in which the dialogues are taking place (such as interpersonal relationships or the location)? }\end{array}$} \\
\hline & 4 & 18 & 20 & 29 & 29 \\
\hline 16 & \multicolumn{5}{|c|}{$\begin{array}{l}\text { How effective are the dialogues in the "Language Functions" section of your textbook in providing you with the opportunity to practice } \\
\text { what you have learned thus far? }\end{array}$} \\
\hline & 3 & 12 & 23 & 32 & 30 \\
\hline 17 & \multicolumn{5}{|c|}{ How effective are these dialogues in causing you to see a reason for learning English? } \\
\hline & 8 & 16 & 17 & 29 & 30 \\
\hline 18 & \multicolumn{5}{|c|}{ How effective are the dialogues in this section of the textbook in fulfilling your daily needs (for reading stories, watching movies, etc.)? } \\
\hline & 11 & 12 & 17 & 28 & 32 \\
\hline 19 & \multicolumn{5}{|c|}{$\begin{array}{l}\text { How effective are the dialogues in this section of the textbook in helping you to speak appropriately (the same way native speakers of } \\
\text { English do)? }\end{array}$} \\
\hline & 7 & 8 & 15 & 31 & 39 \\
\hline 20 & \multicolumn{5}{|c|}{$\begin{array}{l}\text { How effective is the "Language Functions" section of your textbook in providing you with the opportunity to practice the dialogues in this } \\
\text { section? }\end{array}$} \\
\hline & 6 & 9 & 21 & 31 & 33 \\
\hline
\end{tabular}

As Table 3 shows, the number of responses rating the "Language Functions Section" as being ineffective is significantly higher than the number of those rating it as being effective.

TABLE 4:

THE PERCENTAGES FOR QUESTIONS 11-20 IN THE QUESTIONNAIRE

\begin{tabular}{|l|l|l|l|l|}
\hline Highly effective & Somewhat effective & I do not know & Somewhat ineffective & Highly ineffective \\
\hline The Total Number of the Selected Options & 175 & 323 & \\
\hline 62 & 142 & $17.5 \%$ & $32.3 \%$ & 298 \\
\hline The Percentage of the Selected Options & $14.2 \%$ & $62.1 \%$ \\
\hline $6.2 \%$ & $17.5 \%$ & $29.8 \%$ \\
\hline The Merging of the Percentages of the Selected Options & \\
\hline $20.4 \%$ &
\end{tabular}

As Table 4 shows, the percentages of the responses rating the Language Functions Section as ineffective $(62.1 \%)$ are significantly higher than the percentages of those rating them as effective $(20.4 \%)$. The results of the analysis of questions 11-20 in the questionnaire are illustrated in Fig. 2.

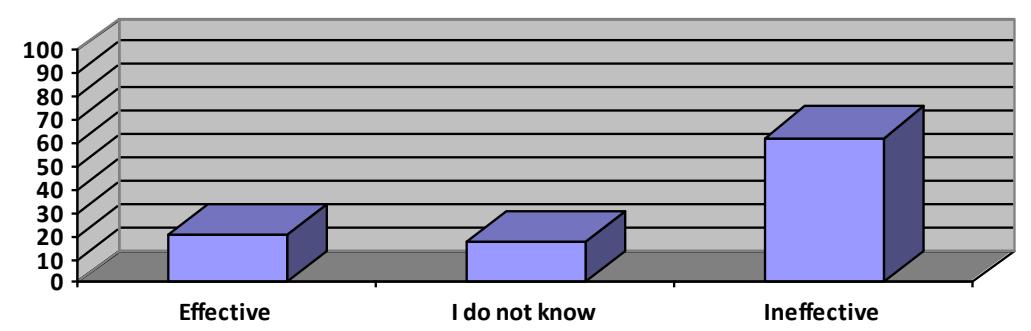

Figure 2.The merging of the results of the analysis of questions 11-20 in the questionnaire

As both Table 4 and Fig. 2 show, only $20.4 \%$ of the responses considered the "Language Functions" section of the textbook as effective, while $62.1 \%$ rated Section $\mathrm{F}$ as ineffective in the learning of English. $17.5 \%$ of the responses were indeterminate.

\section{Descriptive Statistics for Research Question 3}

The types of speech acts in the Language Functions Section of all nine lessons are presented in the Tables below. 
TABLE 5:

SPEECH ACT TYPES IN SECTION F, LESSON 1

\begin{tabular}{|c|c|c|c|}
\hline \multirow{8}{*}{ כa } & & Asking Someone's Name & Speech Act Types \\
\hline & 1 & $\begin{array}{l}\text { A: Excuse me. Are you Henry? } \\
\text { B: Yes. And what's your name? } \\
\text { A: I'm John. }\end{array}$ & $\begin{array}{l}\text { Asking a question } \\
\text { Answering + Asking a question } \\
\text { Answering }\end{array}$ \\
\hline & 2 & $\begin{array}{l}\text { A: What's your first name? } \\
\text { B: My first name is Ali. } \\
\text { A: And what's your last name? } \\
\text { B: My last name is Kabiri. }\end{array}$ & $\begin{array}{l}\text { Asking a question } \\
\text { Answering } \\
\text { Asking a question } \\
\text { Answering }\end{array}$ \\
\hline & & On the Phone & \\
\hline & 3 & $\begin{array}{l}\text { A: May I speak to Mr Amini? } \\
\text { B: Yes, just a moment, please. }\end{array}$ & $\begin{array}{l}\text { Requesting } \\
\text { Granting a request }\end{array}$ \\
\hline & 4 & $\begin{array}{l}\text { A: Could I speak to the teacher? } \\
\text { B: Who's speaking, please? } \\
\text { A: This is Reza. }\end{array}$ & $\begin{array}{l}\text { Requesting } \\
\text { Asking a question } \\
\text { Answering }\end{array}$ \\
\hline & & Introducing a Friend & \\
\hline & & $\begin{array}{l}\text { A: I'd like you to meet my friend, Henry. } \\
\text { B: Glad to meet you, Henry. } \\
\text { C: Nice to meet you, too. }\end{array}$ & $\begin{array}{l}\text { Introducing } \\
\text { Introducing } \\
\text { Introducing }\end{array}$ \\
\hline
\end{tabular}

As Table 5 shows, most of the speech acts in the dialogues in lesson 1 are of two types: Asking and answering questions. The speech act of requesting is not the focus of the lesson. The speech act of introducing has been briefly touched on.

TABLE 6:

SPEECH ACT TYPES IN SECTION F, LESSON 2

\begin{tabular}{|c|c|c|c|}
\hline \multirow{3}{*}{ 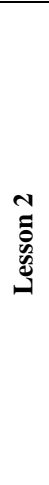 } & & Finding out about People & Speech Act Types \\
\hline & 1 & $\begin{array}{l}\text { A: Where do you come from? } \\
\text { B: I come from Japan. } \\
\text { A: What do you do? } \\
\text { B: I'm a teacher. } \\
\text { A: What's your address? } \\
\text { B: } 172 \text { Azadi Avenue. }\end{array}$ & $\begin{array}{l}\text { Asking a question } \\
\text { Answering } \\
\text { Asking a question } \\
\text { Answering } \\
\text { Asking a question } \\
\text { Answering }\end{array}$ \\
\hline & 2 & $\begin{array}{l}\text { A: Who's that? } \\
\text { B: That's Hassan. } \\
\text { A: Where's he from? } \\
\text { B: He's from Turkey. } \\
\text { A: I see. And what does he do here? } \\
\text { B: I think he's a student. } \\
\text { A: Can he speak Farsi? } \\
\text { B: Yes, he can. }\end{array}$ & $\begin{array}{l}\text { Asking a question } \\
\text { Answering } \\
\text { Asking a question } \\
\text { Answering } \\
\text { Asking a question } \\
\text { Answering } \\
\text { Asking a question } \\
\text { Answering }\end{array}$ \\
\hline
\end{tabular}

As Table 6 shows, the dialogues in lesson 2 consist of only two types of speech acts, namely asking and answering questions.

TABLE 7:

SPEECH ACT TYPES IN SECTION F, LESSON 3

\begin{tabular}{|l|l|l|l|}
\hline & & Asking about Someone's Family & Speech Act Types \\
\cline { 2 - 5 } & $\mathbf{1}$ & A: Do you come from a large family? & Asking a question \\
& B: Yes, I do. & Answering \\
& A: How many are there in your family? & Asking a question \\
& B: Seven. & Answering \\
& A: What does your father do? & Asking a question \\
& & B: He's a doctor. & Answering \\
& & A: What about your mother? & Asking a question \\
& & B: She's a teacher. & Answering \\
\hline
\end{tabular}

Table 7 shows that there is no speech act other than asking and answering questions in the dialogues in lesson 3. 
TABLE 8:

SPEECH ACT TYPES IN SECTION F, LESSON 4

\begin{tabular}{|c|c|c|c|}
\hline \multirow{8}{*}{ 节 } & & Granting a Request & Speech Act types \\
\hline & 1 & $\begin{array}{l}\text { A: May I borrow your pen, please? } \\
\text { B: All right. }\end{array}$ & $\begin{array}{l}\text { Requesting } \\
\text { Granting a request }\end{array}$ \\
\hline & 2 & $\begin{array}{l}\text { A: May I have another sandwich? } \\
\text { B: Yes, of course. Help yourself. } \\
\text { A: Thanks. }\end{array}$ & $\begin{array}{l}\text { Requesting } \\
\text { Granting a request } \\
\text { Thanking }\end{array}$ \\
\hline & 3 & $\begin{array}{l}\text { A: Could I see the newspaper? } \\
\text { B: Yes, of course. Here you are. }\end{array}$ & $\begin{array}{l}\text { Requesting } \\
\text { Granting a request }\end{array}$ \\
\hline & 4 & $\begin{array}{l}\text { A: Can I watch the news on television? } \\
\text { B: Sure. }\end{array}$ & $\begin{array}{l}\text { Requesting } \\
\text { Granting a request }\end{array}$ \\
\hline & & Rejecting a Request & \\
\hline & 5 & $\begin{array}{l}\text { A: Can I use your telephone? } \\
\text { B: Sorry, I'm using it right now. } \\
\text { A: Oh, I see. }\end{array}$ & $\begin{array}{l}\text { Requesting } \\
\text { Rejecting a request } \\
\text { Closing the Request }\end{array}$ \\
\hline & 6 & $\begin{array}{l}\text { A: May I use your car? } \\
\text { B: Sorry. I need it right now. } \\
\text { A: Oh, never mind. }\end{array}$ & $\begin{array}{l}\text { Requesting } \\
\text { Rejecting a request } \\
\text { Closing the Request }\end{array}$ \\
\hline
\end{tabular}

Table 8 shows that the speech act of granting a request, which can be considered as part of the speech act of requesting, is systematically taught in the Section $\mathrm{F}$ of lesson 4.

TABLE 9:

SPEECH ACT TYPES IN SECTION F, LESSON 5

\begin{tabular}{|c|c|c|c|}
\hline \multirow{6}{*}{ 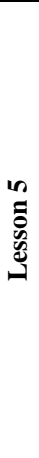 } & & Identifying by Appearance and Dress & Speech Act Types \\
\hline & 1 & $\begin{array}{l}\text { A: Which (one) is Mrs Rasouli? } \\
\text { B: She's the woman with glasses. }\end{array}$ & $\begin{array}{l}\text { Asking a question } \\
\text { Identifying }\end{array}$ \\
\hline & 2 & $\begin{array}{l}\text { A: Which (one) is Mrs Akbari? } \\
\text { B: She's the tall woman. }\end{array}$ & $\begin{array}{l}\text { Asking a question } \\
\text { Identifying }\end{array}$ \\
\hline & 3 & $\begin{array}{l}\text { A: Who's Mr Amini? } \\
\text { B: He's wearing a white shirt. }\end{array}$ & $\begin{array}{l}\text { Asking a question } \\
\text { Identifying }\end{array}$ \\
\hline & & Conversation in Context & \\
\hline & 4 & $\begin{array}{l}\text { Ali: What does your friend look like? } \\
\text { Reza: Well, he's tall. He's about } 180 \text { centimeters. And he's got black hair. } \\
\text { Ali: Does he wear an overcoat? } \\
\text { Reza: No, he doesn't. } \\
\text { Ali: Is he a nice boy? } \\
\text { Reza: Yes, he's very nice. }\end{array}$ & $\begin{array}{l}\text { Asking a question } \\
\text { Describing } \\
\text { Asking a question } \\
\text { Answering } \\
\text { Asking a question } \\
\text { Answering }\end{array}$ \\
\hline
\end{tabular}

As Table 9 shows, the speech act of identifying is taught in the first part of the Section $\mathrm{F}$ of lesson 5, but the second part (conversation in context) mostly consists of only two types of speech acts, i.e. asking and answering questions.

TABLE 10:

SPEECH ACT TYPES IN SECTION F, LESSON 6

\begin{tabular}{|l|l|l|l|}
\hline \multirow{2}{*}{} & \multicolumn{2}{|c|}{ Talking about Appearance } & Speech Act Types \\
\cline { 2 - 5 } & $\mathbf{1}$ & $\begin{array}{l}\text { A: What does he look like? } \\
\text { B: He's quite good-looking. }\end{array}$ & $\begin{array}{l}\text { Asking a question } \\
\text { Answering / Describing }\end{array}$ \\
\cline { 2 - 5 } & $\mathbf{2}$ & $\begin{array}{l}\text { A: How does she look like? } \\
\text { B: She's very beautiful / attractive / pretty. }\end{array}$ & $\begin{array}{l}\text { Asking a question } \\
\text { Answering / Describing }\end{array}$ \\
\cline { 2 - 5 } & Talking about Age, Weight, Hair Color & $\begin{array}{l}\text { Asking a question } \\
\text { Answering / Describing }\end{array}$ \\
\cline { 2 - 5 } & $\mathbf{3}$ & $\begin{array}{l}\text { A: How old is he / she? } \\
\text { B: He / she is twenty five. }\end{array}$ & $\begin{array}{l}\text { Asking a question } \\
\text { Answering / Describing }\end{array}$ \\
\cline { 2 - 5 } & $\mathbf{4}$ & $\begin{array}{l}\text { A: How much do you weigh? } \\
\text { B: I weigh (about) 62 kilos. }\end{array}$ & $\begin{array}{l}\text { Asking a question } \\
\text { Answering / Describing }\end{array}$ \\
\cline { 2 - 4 } & $\mathbf{5}$ & $\begin{array}{l}\text { A: What color is Babak's hair? } \\
\text { B: He's got dark / black / brown / light brown hair. }\end{array}$ & \\
\hline
\end{tabular}

As Table 10 shows, all of the dialogues in lesson 6, Section F consist of the two speech acts of asking and answering questions. The speech act of describing overlaps with the speech act of answering the question in all of the dialogues. 
TABLE 11:

SPEECH ACT TYPES IN SECTION F, LESSON 7

\begin{tabular}{|c|c|c|c|}
\hline \multirow{7}{*}{ ב̃ } & & Requesting Politely - Saying "Yes" to a Request & Speech Act Types \\
\hline & 1 & $\begin{array}{l}\text { A: Will you take these books to the library, please? } \\
\text { B: Sure (certainly). } \\
\text { A: Thanks a lot. } \\
\text { B: Not at all. }\end{array}$ & $\begin{array}{l}\text { Requesting } \\
\text { Granting a request } \\
\text { Thanking } \\
\text { Thanking }\end{array}$ \\
\hline & 2 & $\begin{array}{l}\text { A: Will you turn off the radio, please? } \\
\text { B: Yes, of course. }\end{array}$ & $\begin{array}{l}\text { Requesting } \\
\text { Granting a request }\end{array}$ \\
\hline & 3 & $\begin{array}{l}\text { A: Will you turn down the television, please? } \\
\text { B: All right. }\end{array}$ & $\begin{array}{l}\text { Requesting } \\
\text { Granting a request }\end{array}$ \\
\hline & 4 & $\begin{array}{l}\text { A: Would you give this to Mr Karimi, please? } \\
\text { B: Okay. } \\
\text { A: Thank you very much. } \\
\text { B: You're welcome. }\end{array}$ & $\begin{array}{l}\text { Requesting } \\
\text { Granting a request } \\
\text { Thanking } \\
\text { Thanking }\end{array}$ \\
\hline & 5 & $\begin{array}{l}\text { A: Would you open the window, please? } \\
\text { B: Yes, all right. }\end{array}$ & $\begin{array}{l}\text { Requesting } \\
\text { Granting a request }\end{array}$ \\
\hline & 6 & $\begin{array}{l}\text { A: Would you bring me some water, please? } \\
\text { B: Yes, of course. }\end{array}$ & $\begin{array}{l}\text { Requesting } \\
\text { Granting a request }\end{array}$ \\
\hline
\end{tabular}

Table 11 shows that the speech act of requesting is systematically focused on in lesson 7 , Section $\mathrm{F}$ and the speech act of thanking is only present because it is required in the dialogue rather than being taught systematically.

TABLE 12:

SPEECH ACT TYPES IN SECTION F, LESSON 8

\begin{tabular}{|c|c|c|c|}
\hline \multirow{4}{*}{ 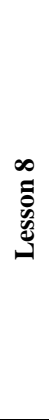 } & & Asking about Other People & Speech Act Types \\
\hline & 1 & $\begin{array}{l}\text { A: Where's John from? } \\
\text { B: He's from Canada. } \\
\text { A: What does he do? } \\
\text { B: He's a mechanic. }\end{array}$ & $\begin{array}{l}\text { Asking a question } \\
\text { Answering } \\
\text { Asking a question } \\
\text { Answering }\end{array}$ \\
\hline & 2 & $\begin{array}{l}\text { A: What's Carl's nationality? } \\
\text { B: He's German. } \\
\text { A: What is he? } \\
\text { B: He's a farmer. }\end{array}$ & $\begin{array}{l}\text { Asking a question } \\
\text { Answering } \\
\text { Asking a question } \\
\text { Answering }\end{array}$ \\
\hline & 3 & $\begin{array}{l}\text { A: Is Ramo Indian? } \\
\text { B: Yes, he is. } \\
\text { A: What's his job? } \\
\text { B: He must be a doctor. }\end{array}$ & $\begin{array}{l}\text { Asking a question } \\
\text { Answering } \\
\text { Asking a question } \\
\text { Answering / Guessing }\end{array}$ \\
\hline
\end{tabular}

As Table 12 shows, the only types of speech acts used in the dialogues lesson 8, Section $\mathrm{F}$ are asking and answering questions. In one instance, the speech act of guessing overlaps with the speech act of answering a question.

TABLE 13:

SPEECH ACT TYPES IN SECTION F, LESSON 9

\begin{tabular}{|c|c|c|c|}
\hline \multirow{3}{*}{ 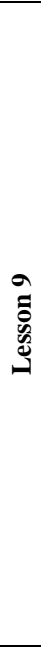 } & & Shopping & Speech Act Types \\
\hline & 1 & $\begin{array}{l}\text { A: May I help you? } \\
\text { B: Yes, I'm looking for a dress. } \\
\text { A: What size do you wear? } \\
\text { B: I wear size } 38 . \\
\text { A: How about this one? } \\
\text { B: It looks nice. How much is it? } \\
\text { A: It's only } 400 \text { tomans. } \\
\text { B: Okay. I'll take it. } \\
\text { A: Anything else, madam? } \\
\text { B: No, thank you. }\end{array}$ & $\begin{array}{l}\text { Offering } \\
\text { Answering } \\
\text { Asking a question } \\
\text { Answering } \\
\text { / Asking a question Offering } \\
\text { Describing + Asking a question } \\
\text { Answering } \\
\text { Accepting an offer } \\
\text { Asking a question } \\
\text { Answering }\end{array}$ \\
\hline & 2 & $\begin{array}{l}\text { A: Can I help you? } \\
\text { B: Yes. I need a watch. } \\
\text { A: How about this one? } \\
\text { B: Is there a cheaper one? } \\
\text { A: Yes, here you are. } \\
\text { B: Thanks. } \\
\text { A: Anything else, sir? } \\
\text { B: No, thank you. }\end{array}$ & $\begin{array}{l}\text { Offering } \\
\text { Answering } \\
\text { Asking a question } \\
\text { / Offering } \\
\text { Asking a question } \\
\text { Answering } \\
\text { Thanking } \\
\text { Asking a question } \\
\text { Answering }\end{array}$ \\
\hline
\end{tabular}

As Table 13 shows, most of the speech acts in the dialogues of lesson 9, Section $\mathrm{F}$ fall into the categories of asking and answering questions. The few instances of other speech acts embedded in the dialogues are not systematically taught. 
The first research question was how effective speech acts are in the learning of English from the perspective of Iranian high school students. $76.7 \%$ of the responses rated the learning of speech acts as being effective in the overall learning of English and $14.2 \%$ considered them as being ineffective, so the answer is that students consider the teaching of speech acts as being highly effective in their learning of English.

The second research question was how effective the Language Functions section of the textbook is in the learning of English from the perspective of Iranian high school students. Only $20.4 \%$ of the responses considered the "Language Functions" section of the textbook as being effective, while $62.1 \%$ rated this section (section F) to be ineffective. This means that the majority of the students consider section $F$ to be ineffective in the learning of English.

The third research question was what the range of speech acts taught in Iranian high school textbooks is. The examination of the dialogues in the "Language Functions" section of the textbook revealed that the speech acts used in these dialogues are extremely limited in range. Asking questions, answering, describing, identifying, thanking, introducing, requesting (granting/rejecting a request), offering (rejecting/accepting an offer), and guessing are the only kinds of speech acts some instances of which have been embedded in the dialogues in this section. Moreover, only one type of speech act has been systematically introduced to the students, namely requesting. The great majority of the speech acts in the dialogues in this section are asking and answering questions. The few instances of other speech acts (aside from requesting) are not systematically taught and are present in some of the dialogues only because they are required in that particular dialogue. Moreover, most of the dialogues are organized around topics rather than speech acts. While the teaching of speech acts can help the learners to perform a variety of speech acts in different situations, the organization of dialogues around topics limits what the students can talk about. The number of the topics/subjects one can talk about is extremely broad and an attempt to capture them all seems to be rather impractical. The common types of speech acts, however, can be extended to various situations and have more benefits for the learners as their responses have demonstrated. Speech acts can be practiced in role playing tasks, which can be highly motivating both in providing the students with the opportunity to practice speech acts and in their potential to be performed in the form of motivating role playing tasks.

What is common among most of the dialogues in the "Language Functions" section of the textbook is that neither the interlocutors nor the context has been specified in the dialogue. Indetermination of context in the dialogues can affect even the simplest dialogues. For example, this can cause the dialogue in lesson 1, in which one of the participants is enquiring the first name and last name of the other participant, to sound artificial because such a formal exchanging of information is limited to certain formal contexts and is rarely used in everyday life. This and the drawbacks that will be pointed out could have contributed to the poor rating of these dialogues by the students. Below, the dialogues in the "Language Functions" section of the textbook are examined more closely:

Lesson 1: In the section $F$ of lesson 1, four types of speech acts have been used in the dialogues, the majority of which are asking and answering questions. The second dialogue seems to aim at teaching two new words, "first name" and "last name", both of which appear in the vocabulary list. This is evident through the repetitive use of the two words as in "My first name is Ali." rather than giving a short answer such as "Ali". The first and second dialogues intend to talk about a specific topic (asking someone's name) and make use of the relevant vocabulary (name, first name, last name) and formulaic expressions such as "Excuse me" and "What's your name?" The proper usage of "Excuse me" is not highlighted, unless the teacher points out that it can be used before making a request so that students do not wrongly assume, through literal translation, that it is used for apologizing.

The third and fourth dialogues are organized around a topic (how to begin a conversation on the phone), but they do not attempt to specify the kinds of speech acts used in this situation. The third dialogue ignores other possibilities such as rejecting the request or giving a negative answer such as "Sorry, he's not available". Both "may" and "could" in dialogues 3 and 4 are modal verbs. The students are already familiar with the word "may" from guidance school, but the author has used this situation to remind the students of the usage of "may" and at the same time to introduce a new usage for "could". The students become familiar with "could" as the past form of "can" in the first lesson in high school, but are never directly taught that "could" can be used to make requests. This usage of "could" in dialogue 4 does not match with what students have learned about "could" in lesson 1 as meaning "the ability to do something in the past".

The fifth dialogue can be roughly categorized as an speech act; i.e. introducing, but it is far from being comprehensive, because there are a number of different ways in which one can introduce two people to each other.

Lesson 2: Neither of the two dialogues in lesson 2 is based on speech act types. They are merely a set of questions and answers whose primary purpose seems to be the use of "wh" question words to ask questions about someone else. What's more is that the situation presented in of the dialogues is uncommon. For instance, the first dialogue talks about a Japanese person who is a teacher in Iran, which can be readily understood from the street name (Azadi Avenue). This could make it difficult for students to connect with the dialogues.

Lesson 3: Just like the dialogues in lesson 2, the dialogue in lesson 3 revolves around questions and answers. No information has been given on the place of conversation or the interlocutors.

Lesson 4: The "Language Functions" section in lesson 4 teaches one kind of speech act; i.e. granting / rejecting a request, which can be considered as part of the speech act of "requesting". However, what has been neglected is that students have not been introduced to different ways of making a request; i.e. while they recognize the modal verbs "may", "could", and "can", they have not been taught how they can be used to make requests. It is only logical that 
students be taught different ways of making a request before being introduced to the kinds of responses that they can give to a request.

Lesson 5: While identifying is considered as a speech act, due to limiting it to appearance and dress, its scope is narrow here. The first three dialogues present situations in which it is presumed that a number of people are all in the same place and one person is asking the other to tell him/her which of the people present in their immediate environment is the one he/she is trying to find. The sentence said in response to their question is one that includes the definite article "the" as in "She's the tall woman", which is the case when the respondent is identifying the target by their appearance. In the case of identifying the target by their dress, the respondent uses the present continuous tense as in "He's wearing a white shirt / glasses / a hat". No explanation has been given in this regard.

The "conversation in context" is different from the first three dialogues in that it is more about describing a person's looks in general rather than identifying them in the immediate environment of conversation. This is clear from the absence of the article "the" in "He's tall" rather than "He's the tall boy.", and also the verb tense used in the question "Does he wear an overcoat?" rather than "Is he the one wearing an overcoat?". Moreover, "he's very nice." is a statement that is describing a person in general, which has nothing to do with their appearance or outfit.

Lesson 6: The first three dialogues are describing a person's looks in general. The aim is to distinguish between the adjectives that are used to describe males (i.e. good-looking) and those that are used to describe females (i.e. beautiful, attractive, and pretty) rather than teaching speech acts. In dialogues 4, 5, and 6 some physical attributes are discussed (i.e. age, weight, and hair color). These utterances perform the speech act of describing.

Lesson 7: Here, the speech acts of (polite) requesting and granting a request are taught. Granting a request can be considered as part of the speech act of requesting. The dialogues do not explicitly teach the grammatical patterns often used in polite requests (Will you + do something (imperative) + please? / would you + do something (imperative) + please?), which could be confusing to students.

Lesson 8: The dialogues in this section are comprised of a set of questions and answers. The aim is to teach the name of countries and nationalities rather than speech acts. This is evident from the table that immediately follows the three dialogues. In the table, a list of countries is given. In front of each country, the respective nationality is presented.

Lesson 9: The dialogues in this lesson aim to demonstrate how English can be used to do shopping and what some of the common expressions in this situation are (Can I help you?, How much is it?, I'll take it., Anything else?). The problem with both dialogues is that they are truncated and are unlikely to happen in the real world in the way they are presented. For instance, in the first dialogue the shopper buys the dress without first trying it on. The rate used in the dialogue (tomans) suggests that the conversation is taking place in Iran. Clearly, English is not commonly used in Iran in such a situation, which fails to show why learning English can be useful. Moreover, the way an English speaker does shopping and the kinds of expressions used by both the buyer and the seller are determined by the culture they belong to. This issue needs to be addressed in the textbook. Since the textbook has not been updated for a long time, the price suggested for the dress (400 tomans) is no longer believable.

The second dialogue may seem unnatural for an Iranian reader. Since the store likely has dozens of models, "How about this one?" is highly unlikely to be said in a real situation. Being detached from reality can be demotivating for learners since they fail to illustrate a realistic use for the language that is being learned.

The results of this study suggest that there are mismatches between the actual content of the textbook and what the students perceive to be motivating and useful in the learning of English. These results can be useful to textbook designers who are willing to consider the perceptions of learners in the possible future revisions of high school textbooks. It can also give language teachers at high school level some insights about what their students perceive to be effective in the learning of English, and to what aspect of language they need to allocate more time in order to compensate for the shortcomings of the textbook. The results of the study would still be valid in the event of high school textbooks undergoing revision in the future, since the results reflect the preferences of learners which could be compared to the content of the revised textbooks, or may even be taken into consideration in future revisions.

\section{ApPendix A The English Version of the Questionnaire}

Below, you see some samples of speech acts with an example in front of each. Please read about them and answer the following questions.

\section{Answering:}

\section{Greeting: \\ Requesting: \\ Agreeing / disagreeing:}

Apologizing:
Thanking:
Offering:
Asking:
Denying:

Ali: Can he speak English?

Reza: Yes, he can.

Ali: Hi. How are you doing today?

Ali: May I borrow your pen for a minute, please?

Ali: The new lesson is really difficult.

Reza: You're right. / I don't think so. It's easy for me.

Ali: I'm sorry for being late.

Ali: Thank you for your help.

Ali: Would you like some biscuit?

Ali: Give me your pen, please.

Teacher: Ali, did you make that noise? 


\section{Agreeing to do something: Reza: Let's go to the cinema.}

Ali: That's a good idea. Let's go.

1. How effective can practicing such speech acts be in making language learning enjoyable?

$\square_{\text {Highly effective } \quad \square} \square_{\text {Somewhat effective }} \square_{\text {I do not know } \quad \square} \square_{\text {Somewhat ineffective }} \square_{\text {Highly ineffective }}$

2. How effective can learning such speech acts be in increasing your motivation to speak in English?

$\square$ Highly effective $\square$ Somewhat effective $\square$ I do not know $\square$ Somewhat ineffective

3. How effective can learning such speech acts be in causing you to see a reason for learning English?

$\square$ Highly effective $\square$ Somewhat effective $\square$ I do not know $\square$ Somewhat ineffective $\square$ Highly ineffective

4. How effective can learning such speech acts be in providing you with the opportunity to practice what you have learned thus far?

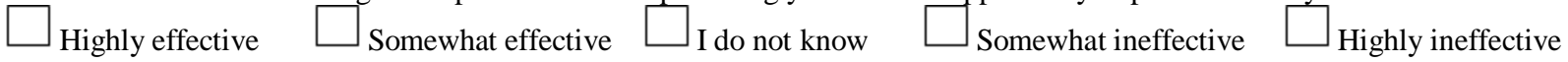
5. How effective can practicing such speech acts be in improving your vocabulary knowledge?

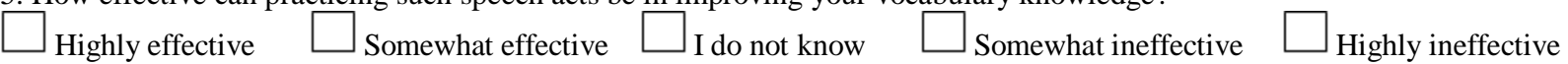
6. How effective can practicing such speech acts be in increasing your mastery over grammatical structures?

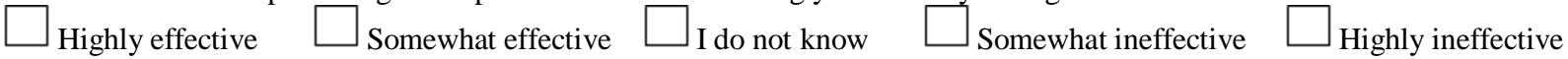
7. How effective can practicing such speech acts be in improving your pronunciation?

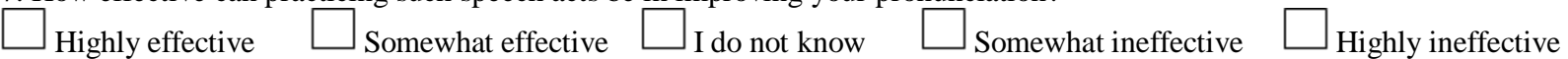

8. How effective can learning such speech acts be in carrying out in-group interactions while performing the kinds of tasks that you were introduced to in the beginning of the questionnaire?

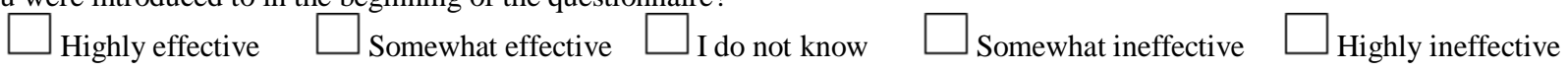
9. How effective can learning such speech acts be in helping you to speak appropriately (the same way native English speakers do)?

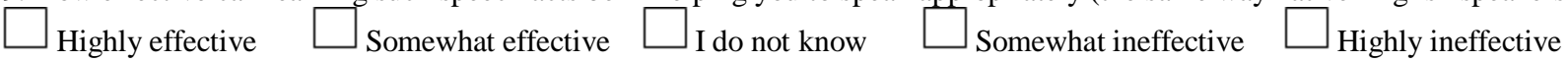
10. How effective can learning such speech acts be in fulfilling your daily needs (for reading stories, watching movies, etc.)?

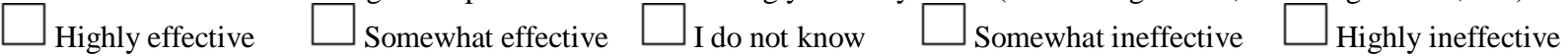

The following questions are about the Language Functions Section of your textbook (the last page in each lesson).

11. How effective is the "Language Functions" section of your textbook in increasing your motivation to speak English?

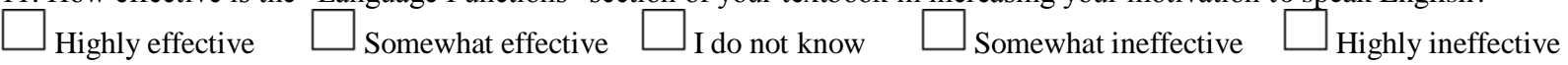
12. How effective are the dialogues in the "Language Functions" section of your textbook in enabling you to speak English?

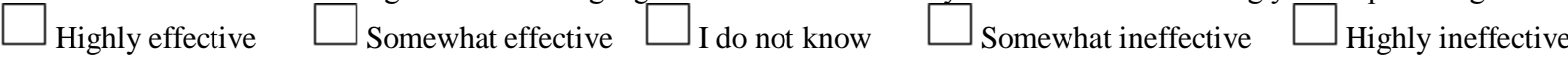
13. How effective are these dialogues in familiarizing you with various speech acts?

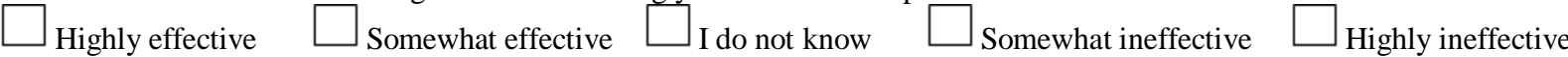

14. How effective are the dialogues in the "Language Functions" section of your textbook in making these dialogues meaningful to you? (for example, by giving information on the speakers involved or presenting you with pictures)

$\square_{\text {Highly effective }} \square_{\text {Somewhat effective }} \square_{\text {I do not know }} \quad \square_{\text {Somewhat ineffective }} \square$ Highly ineffective

15. How effective are the dialogues in the "Language Functions" section of your textbook with respect to presenting you with information on the situation in which the dialogues are taking place (such as interpersonal relationships or the location)?

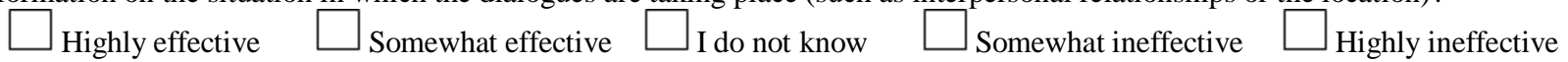

16. How effective are the dialogues in the "Language Functions" section of your textbook in providing you with the opportunity to practice what you have learned thus far?

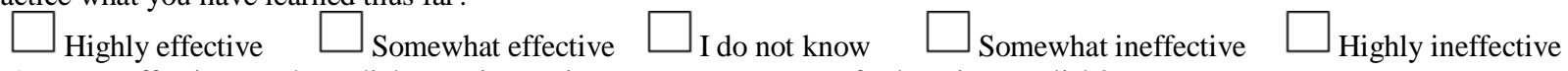

17. How effective are these dialogues in causing you to see a reason for learning English?

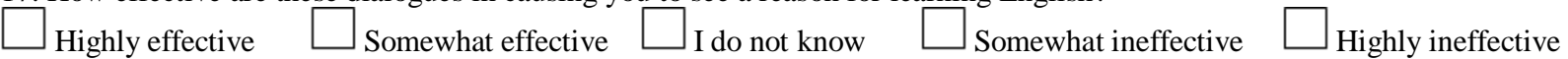

18. How effective are the dialogues in this section of the textbook in fulfilling your daily needs (for reading stories, watching movies, etc.)?

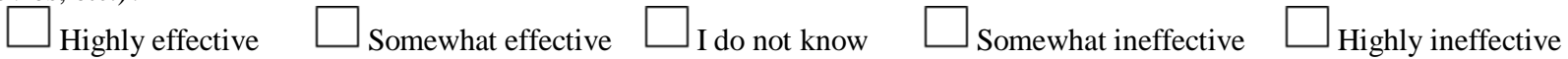

19. How effective are the dialogues in this section of the textbook in helping you to speak appropriately (the same way native speakers of English do)?

$\square$ Highly effective $\quad \square$ Somewhat effective $\quad \square$ I do not know $\quad \square$ Somewhat ineffective $\square$ Highly ineffective

20. How effective is the "Language Functions" section of your textbook in providing you with the opportunity to practice the dialogues in this section?

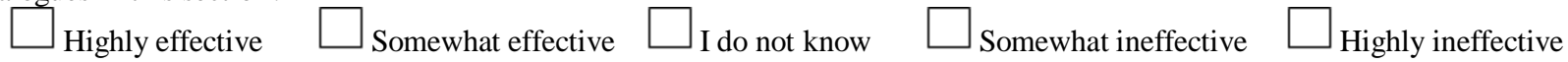

\section{REFERENCES}

[1] Amiryousefi, M., \& Ketabi, S. (2011). Anti-textbook arguments revisited: A case study from Iran. Procedia Social and Behavioral Sciences, 15, 215-220. 
[2] Ansary, H., \& Babaii, E. (2002). Universal characteristics of EFL/ESL textbook: A step towards systematic textbook evaluation. The Internet TESL Journal, 2, 1-8.

[3] Azizifar A., Koosha, M., \& Ahamd R. (2010). An analytical evaluation of Iranian high school ELT textbooks from 1970 to the present. Procedia Social and Behavioral Sciences, 3, 36-44.

[4] Baleghizadeh, S. (2007). Speech acts in English language teaching. Iranian Journal of Language Studies, 1(2), 41-52.

[5] Culler, J. (2000). Literary theory: A very short introduction. Oxford: Oxford University Press.

[6] Harmer, J. (2001). Coursebooks: A human, cultural and linguistic disaster?. Modern English Teacher, 10(3), 5-10.

[7] Hutchinson, T., \& Torres, E. (1994). The textbook as agent of change. ELT Journal, 48(4), 315-328.

[8] Jaworowska,J.(2012).Speech act theory. Retrieved June 5, 2012 from http://instructional1.calstatela.edu/lkamhis/tes1565_sp04/troy/spchact.htm

[9] Liu, J., Chang Y., Yang, F., \& Sun Y. (2011). Is what I need what I want? Reconceptualizing college students' needs in English courses for general and specific/academic purposes. Journal of English for Academic Purposes, 10, 271-280.

[10] McGrath, I. (2002). Materials evaluation and design for language teaching. Edinburgh: Edinburgh University Press.

[11] O'Neill, R. (1982). Why use textbooks?. ELT Journal, 36(2), 104-111.

[12] Rahimi, M., \& Hassani, M. (2012). Attitude towards EFL textbooks as a predictor of attitude towards learning English as a foreign language. Procedia Social and Behavioral Sciences, 31, 66-72.

[13] Schmitt, N. (2002). An Introduction to applied linguistics. London: Arnold.

[14] Seedhouse, P. (1995). Needs analysis and the general English classroom. ELT Journal, 49(1), 59-65.

[15] Smith, B. (2003). 'John Searle: From speech acts to social reality', In Barry, Smith (Ed.) John Searle (pp. 1-14). Cambridge: Cambridge University Press.

[16] Tomlinson, B. Dat, B., Masuhara, H., \& Rubdy, R. (2001). ELT courses for adults. ELT Journal, 55(1), 80-101.

[17] Vellenga, H. (2004). Learning pragmatics from ESL \& ESL textbooks: How likely?. TESLEJ, 8 (2). Retrieved 12 April, 2012 from http://www.teslej.org/wordpress/issues/volume8/ej30/ej30a3/

[18] Yarmohammadi, L. (2002). The evaluation of pre-university textbooks. The Newsletter of the Iranian Academy of Science, 18, 70-87.

Mohsen Sa'di Khosroshahi: M.A. student in Teaching English as a Foreign Language (TEFL), studying at University of Tabriz, Iran. He got his B.A. in TEFL at Shahid Madani Azarbaijan University, Iran.

Farahman Farrokhi: The Dean of Faculty at Faculty of Persian literature \& foreign languages at University of Tabriz. From 2010 onwards he has been the Associate Professor at the University of Tabriz. He got his B.A. from Allameh Tabatabaii UniversityTehran, his M.A. from Tarbiat Modarres University - Tehran, and his Ph.D. from University of Leeds - UK. He is the supervisor of the thesis based on which this paper was written. 